\title{
FISCAL POLICY AND PROVINCIAL GROWTH: THE CASE OF VIETNAM
}

\author{
Nguyen Thi Nguyet* \\ Central Institute for Economic Management (CIEM) - Ministry of Planning and Investment (MPI), \\ Hanoi City, Vietnam
}

This paper focuses on the evaluation of the impact of the fiscal policy on the growth of Vietnam at the provincial level. A fiscal policy plays a huge role in a national economy. Policy-makers often use flexible fiscal and monetary policies to achieve the overall goal of economic growth. In order to assess the impact of the fiscal policy instruments on economic growth, integrated analyses combined with quantitative analyses are used in the paper so as to find the relationship between the key expenditure items. The government has an impact on economic growth. The results and methodology will elicit quantitative approaches in policy reviews.

Keywords: fiscal policy, fiscal decentralization, tax, expenditure, growth

JEL Classification: $\mathrm{H}_{3} \mathrm{O}, \mathrm{H} 70, \mathrm{H} 2 \mathrm{O}$

\section{INTRODUCTION}

Since the economic reform began in 1986, Vietnam has been making a shift into a socialist-oriented market economy, so it could not avoid the economic cyclicality of fluctuating up and down. So as to stabilize - "flatten" the economic cycle, the majority of countries in the world need the hands of the state to moderate the cyclicality of their markets. The fiscal policy is certainly one of the powerful instruments of the "hands of the state" with that respect.

* Correspondence to: N. T. Nguyet, Vietnam Economic Management Review (VEMR), Central Institute for Economic Management (CIEM) - Ministry of Planning and Investment (MPI), 68 Phan Dinh Phung St., Ba Dinh District, Hanoi City, Vietnam; e-mail: nguyetnt@mpi.gov.vn
Not only does an ineffective fiscal policy do harms to economic potentials and stability, but it may also cause an economic recession, and even lead to a political crisis and a comprehensive crisis as well. A public debt crisis that has been taking place throughout Europe, typically in Greece, Ireland and Portugal, is a practical piece of evidence for this assertion. Therefore, a prudent fiscal policy is required in order to stabilize the economic cycle and drive sustainable growth.

In the world, the fiscal policy is implemented in various ways; still, there are a lot of failures and controversial debates. The theory of the fiscal policy itself is not perfect because its development history is formed in the context of the "boundary"- often 
attached to a single country or a certain scope of space, rather than being adjusted in the new context of the "non-boundary" - integration and globalization, as it is the case today. Similarly, the monitoring of the fiscal policy in Canada, Sweden, Japan and the US or Chile shows that an expansionary fiscal policy is not always effective in stabilizing the economic cycle. Furthermore, the fiscal decentralization policy in China, Brazil, or India also delivers different impacts towards the stabilization of the economic cycle. Besides, there are many questions in place: why did the "golden rule" emerge and why has it been effective in the UK, but not in other countries as well? Why does Chile succeed in regulating its fiscal policy, on the one hand, whereas, on the other, it is not a powerful economy? So, what is it that determines the effectiveness of a fiscal policy? Where is the "golden key" to the fiscal policy needed to stabilize the economic cycle? Each policy has its own features and is associated with a different success. So, what are such conditions, which factors and instruments may enable us to determine the successfulness of a fiscal policy? All these show that the fiscal policy resembles an "art", requiring a solid foundation of theory and practical experience. Therefore, this affirms the need for conducting a further research study of both theories and fiscal decentralization.

In Vietnam, since the financial crisis of 2008-2009, the great efforts the Government has made with respect to finding out the way out for the economy seem to be disabled. The Government has implemented the fiscal instruments in coordination with a monetary policy intervention; the most outstanding is the USD 8-billion-worth stimulus package intended to overcome the influences of the crisis. However, the economic growth has not met the expectations: there has been a significant drop in attracting FDIs; many public investment projects have been inefficient with an ICOR greater than 5; the inflation has become unexpectedly instable, and the same situation has been evident with respect to the interest rate in the financial and banking systems. On the other hand, because Vietnam is becoming more broadly and more deeply integrated into the world economy, the estimated trade openness of the country moves around $150 \%$, which has been computed by having taken into account the total import and export revenue over the GDP; the risk of macroeconomic instability is larger due to the fact that it has been suffering from the negative fluctuation of the world economy. Furthermore, there is evidence showing that the Vietnamese economy is cyclical and that the fiscal policy of Vietnam tends to be pro-cyclical, with an ever-increasing number of the limitations in the fiscal policy management (Nguyen, 2014; Le, 2017). If this pattern of the low efficiency of the fiscal policy continues to exist and apply, as it is a reality in other countries, its economy may be in danger of entering into a crisis with unpredictable consequences. Therefore, it is highly necessary to find out solutions to the right fiscal policy and there is also the need for coming to a comprehensive framework of the theories of the fiscal policy in order to stabilize the economic cycle.

The issue becomes more urgent when looking at reality up to date; Vietnam is still lacking in a comprehensive theoretical framework of the fiscal policy towards the stabilization of the economic cycle and in the new context of integration and globalization; this leads to the absence of the solid scientific basis suitable for the local conditions with the aim of adjusting and perfecting the fiscal policy, thus leading to sustainable development. Thus, the forecast and the policy recommendation and the planning and exercising of the fiscal policy are all but convincing and successful.

From the reality as the same has been described above, this project is expected to provide us with a theoretical framework of the fiscal policy towards stabilizing the economic cycle that would be coherent, comprehensive and updated to the largest possible extent. In the paper, the theories and the analytical models are systematized and the empirical studies are assessed so as to extract the experience lessons in monitoring the fiscal policy. On the basis of the theoretical and empirical research study, the paper will provide the scientific and practical bases and the arguments, and will be the founding study for further empirical studies in Vietnam afterwards, and for the most part, it will provide the theoretical bases as guidance to and directions for managing the fiscal 
policy effectively in the current context, as well as the basis for the policy planning for future governments.

Therefore, based on an in-depth literature review, this paper concentrates on the main question of how the fiscal policy affected provincial growth in the period from 2006 to 2015, an episode of the strong market economy towards the socialist-oriented one in Vietnam, and which conditions supported the impact.

The hypothesis that the fiscal policy supports provincial economic growth is tested by applying the S. Devarajan, S. Swarop and H. F. Zou (1996) method with the OLS and random-effect models.

The answer may raise the policy implications for Vietnam so as to improve the efficiency of the fiscal policy. The remaining part of the paper is organized as follows: In Section 2, the employed methodology including the model, the variables, and the data is briefly described. Section 3 is focused on the empirical results and analysis. In the final section, the conclusions are given and certain policy implications are highlighted.

\section{LITERATURE REVIEW}

\section{Literature Review in the World}

The global financial crisis in the period from 2008 to 2009 once again showed the fact that economic cycles take place unpredictably, simultaneously forcing governments to intervene in the economy in order to limit its negative impacts on the operation of markets. In parallel with that, the studies of the role of the fiscal policy towards stabilizing the economic cycle have been executed so as to correctly assess the power of the fiscal instruments and the effectiveness of the Government's management of the policy. For example, X. Debrun and R. Kapoor (2010) construct a regression model in order to analyze the data of 49 countries, including both developed and developing ones. They find that automatic stabilizers reduce the variation in the output, so, these instruments could stabilize the economic cycle.
Having studied the fiscal policy in Chile, M. Gutiérrez and J. E. Revilla (2011) found that a prudent fiscal policy stance from the good times of the economy was very important for the government to follow a counter-cyclical fiscal policy in bad times and avoid the negative influence on the economic cycle. This implication can also be seen with M. Floden (2012) in the case of the Swedish economy during the past two decades.

Recently, there have been a larger number of the studies conducted that have placed an interest in the fiscal policy as a powerful instrument for the stabilization of the economic cycle. These studies focus on the modelling theories in order to implement an empirical research study based on the real data of economic variables. These models focus on estimating the fiscal multiplier in order to assess the link between the multiplier and the state of the economy. More specifically, estimated multipliers show how and to what extent the fiscal tools (will) result in and increase or decrease in aggregate demand; then, policy-makers would intervene in order to change the economic cycle through the multiplier effect. However, different estimation methods under different economic conditions derive the different and various results that show that the fiscal policy has multi-dimensional effects on the economic cycle itself. The following are the major studies analyzing the impact of the fiscal policy through constructing empirical models:

The SVAR (Structural Vector Autoregressive) model has been well-used to analyze the impacts of the monetary policy by B. S. Bernanke (1986), S. R. Aiyagari, L. J. Christiano and M. Eichenbaum (1992). O. Blanchard and R. Perotti (2002), however, are considered as the pioneers in applying this model in analyzing the impacts of the fiscal policy. They think that a discretionary fiscal policy does not contemporaneously respond to change in the economic output, so they construct a SVAR model, whose critical point is the technique of identifying fiscal shocks. Having applied the said model and technique in analyzing the data in the US for the period 1947-1997 in order to estimate the multiplier, the two economists concluded that the expansionary fiscal policy could raise the output; however, 
government spending was crowding out with a part of private investment. The conclusion implies the fact that the fiscal policy bears both positive and negative impacts on the economic cycle.

Using O. Blanchard and R. Perotti's (2002) technique, another research study at the national level includes: R. Shaheen and P. Turner (2010), having applied it in Pakistan for the period from 1973 to 2008 found out that government spending generated positive impacts on the GDP level and the inflation, that the spending multiplier was positive in the short term, but the same was negative in the long run; the shocks in government spending, as well as the increase in the tax rate, led to an increase in the interest rate. These results imply that the expansionary fiscal policy may reduce a long-term output, although it may also raise an output in the short run, for which reason the same may negatively affect the economic cycle.

Applying SVAR to five countries in the OECD, R. Perotti (2005) had also been analyzing these five countries in the OECD approximately two years before and reaffirmed that the impacts of an increase in government spending or a decrease in the tax rate on the GDP are minor and that the same had a downtrend over time, that a multiplier greater than 1 could only be found in the US before 1980, and that a decline in the variance of fiscal shocks would lead to a decline in the GDP variations.

Apart from the technique offered by O. Blanchard and R. Perotti (2002), A. Mountford and H. Uhlig (2008) construct another SVAR model to assess the effects of the fiscal policy, but they apply another approach so as to identify fiscal shocks; the model purely utilizes the methodology of analyzing time series data, does not require an assumption about the non-contemporaneous response of the fiscal policy or another auxiliary information to identify fiscal socks as in O. Blanchard and R. Perotti (2002). This model could forecast effects due to innovation in the fiscal policy in the future, could distinguish change in the fiscal variable due to a fiscal shock, a business cycle or shocks in the monetary policy. Based on the quarterly data in the US for the period from 1955 to 2000, the two economists find that the best fiscal policy is that intended to reduce tax and the cost of the expansionary fiscal policy in the long run is greater than the benefit achieved in the short run.

More recently, K. Mertens and M. O. Ravn (2012) have extended the SVAR model with respect to the assessment of the impact of the fiscal policy under the assumption that fiscal shocks could be anticipated, specifically a change in the tax rate; the authors do not find any policy anticipation effects on aggregate demand; a decrease in tax always influences an increase in the output, consumption and investment. Thus, the fiscal policy has a positive impact on the economic cycle through a tax instrument.

M. Baxter and R. G. King (1993) were the pioneers in using the GE model in order to quantify the impact of the fiscal policy. They found multiplier effects in the long run, associated with government spending, that a permanent change in government spending has greater effects than a contemporaneous change, and that public investment demonstrated great impacts on the output and private investment.

F. Lorenzo, M. Libero and S. Luca (2009) applied the DSGE model and added a proportion of non-Ricardian households in order to estimate the impacts of the fiscal policy in Europe, and the findings they came to have shown that the effects of government spending are minor. More specifically, change in fiscal variables seems to prolong, government spending leads to an increase in private consumptions in the short run, whereas changes in social welfare generate greater multiplier effects for the household; a cut in income tax and consumption tax strongly impacts the output and consumption, and a cut in capital income tax would influence private investment in the medium term, so these instruments of the fiscal policy could well be able to stabilize the economic cycle.

D. Furceri and A. Mourougane (2010) developed a fiscal DSGE model with an endogenous government bond yield so as to assess the impacts of the fiscal policy on the output, its components and the public debt pattern in the OECD countries. The simulations of the model show that the fiscal policy has positive effects on the other economic activities, especially in the short term. Bigger multipliers are found in 
public investment, public spending and a decrease in income tax. The multipliers also depend on liquidity constrained to households; therefore, given the effectiveness of financial markets, the fiscal policy could help stabilize the economic cycle.

Some other studies applying the DSGE regarding the impacts of the fiscal policy could also be found in S. R. Aiyagari, L. J. Christiano and M. Eichenbaum (1992), V. A. Ramey and M. D. Shapiro (1998), A. Kriwoluzky (2009), V. A. Ramey (2008), F. M. Leeper, F. B. Walker and S. S. Jang (2008).

Apart from evaluating the role of the fiscal policy in stabilizing the economic cycle through the models of a quantitative analysis as previously mentioned, there is one method of identifying the fiscal stance that is widely used by the economists of the IMF, and that is the measuring of the fiscal impulse. The fiscal impulse is defined as the difference between the cyclical adjusted fiscal balance in the year $t$ and the actual fiscal balance in the year $(t-1)$. The cyclical adjusted fiscal balance or structural fiscal balance means a balance with an assumption that the economy is operating at a potential output, keeping the economic conditions in the previous year unchanged. Therefore, the fiscal impulse is used to assess the impacts of the discretionary fiscal policy towards aggregate demand, and does not take the cyclical changes into account.

Increases in the structural deficit (surplus) will imply an expansionary fiscal impulse. In various periods of the economic cycle, the fiscal impulse can show that the fiscal stance of a country is either loose or tight. Therefore, the fiscal impulse can be used to assess the impacts of the fiscal policy on aggregate demand at a certain level. The fiscal impulse successively expands for the period of time when the economic output is already above the potential output, which means that the fiscal policy is not applied effectively, because the government is following a pro-cyclical policy rather than a counter-cyclical policy, which in the long run will have negative impacts on the stabilization of the economic cycle.

J. S. Garry (1986) studies and points out the different measurement of the fiscal impulse by the OECD and the IMF and the strength of such a different measurement, illustrating it with the data in some countries, whereas P. Renee and J. John (2002) study and develop the indicators for the fiscal impulse that are appropriate for the assessment of the impacts of the fiscal policy on the economic cycle through the responses to the aggregate demand in New Zealand.

Economic theory suggests that fiscal decentralization (FD) would increase economic growth. The empirical findings, however, are much more ambiguous. $\mathrm{H}$. Davoodi and H. Zou (1998) are probably among the first to have empirically investigated this question. They used a panel of 46 countries between the years 1970-1989 in order to measure the effect of the FD on growth and find a negative link between the FD and growth in developing countries, but no link in developed economies.

Still, other studies focus on a specific country, such as the US or China. N. Akai and M. Sakata (2002) analyzed a cross-section of the US states and found a positive link between decentralization and economic growth. D. Stansel (2005) analyzed a cross-section of the 314 US metropolitan areas and came to similar conclusions. Both studies rely on a constant measure of fiscal decentralization, which might be correlated with unobserved attributes at the state level. They also have a very limited sample size of 50 states. Indeed, their results fail to survive robustness checks. D. Xie, H. Zou and H. Davoodi (1999) provide us with a time series for the US data, and suggest that the relationship between decentralization and growth is non-linear, and that there is an optimal level of decentralization.

\section{Literature Review in Vietnam}

Central Institute for Economic Management - CIEM (2010), the research study entitled "Fiscal-Monetary Policies Stabilizing Macroeconomics and Promoting Economic Growth in Vietnam", reviews the general situation when the fiscal and monetary policies in the recent years, especially in 2009, are concerned. The research study pronounces the different determinants that could affect macroeconomic issues and growth, and on this basis it provides a few suggestions for the implementation of these two policies in the short 
run, in the medium run and in the long run, with the purpose of boosting growth in 2010 and years afterwards.

The CIEM (2011) - the research study entitled "The Fiscal Policy and the Budget System" reviews the regulation of the fiscal policy and the budget system of Vietnam with respect to some important items, such as: the budget revenue, government spending, decentralization in managing and using the state budget etc. The research study recommends some solutions to stimulate economic growth.

Studying the impacts of the stimulus packages of the government in response to the 2008-2009 global financial crisis, N. A. Nguyen, D. C. Nguye, D. N. Nguyen and T. H. Bui (2010) concluded that those fiscal solutions bear certain effectiveness associated with the positive effects of easing the monetary policy.

D. A. Vu (2011), a Ministerial-level research project: "Coordinating the Fiscal Policy and the Monetary Policy to Stabilize Macro-Economics and Promote Economic Growth over the Period 2006-2010", outlined a number of the issues regarding the coordination of the fiscal policy and the monetary policy in Vietnam during the past few years. Based on the study, he recommends some solutions to the coordination of the two policies with respect to the stabilization of macro-economics and driving growth for the period 2006-2010.

T. K. T. Nguyen (2013) mentions the pattern of coordinating the fiscal policy and the monetary policy, pointing out the limitations in the policy management and the recommendation; the author suggests that empirical models should be constructed so as to identify a suitable policy under specific circumstances and that a policy instrument should be quantified in order to assess the impacts of an individual policy on aggregate demand.

P. L. Nguyen and S. Anvar (2011) examines the impacts of fiscal decentralization on the provincial economic activities and finds that the decentralization of public investment exerted positive influences on the provincial economic growth over the period 2002-
2007, but that it also had negative influences over the period 1997-2001, the time immediately after the Asian financial crisis. This means that in the different phases of the economic cycle fiscal decentralization has different impacts on the provincial growth and the economic cycle of the country as a whole. The author also finds that, in both periods mention above, the decentralization of the current expenditure generates negative impacts on growth.

Besides, there have also been research studies focused on the role of the fiscal policy when the stabilization of the economic cycle is concerned. H. M. Dinh (2005), with the non-parameter approach to the constructing of the general indicators for the economic cycle, through the Period Average Trend (PAT) methodology and the maximization of the simple correlation coefficients, came to the study's preliminary results showing that Vietnam seems to have a growth cycle. Recently, D. T. Su (2013) has carried out a study of the impact of the Vietnamese fiscal stance over the period 1994-2008 by applying the approach of measuring the fiscal impulse and has demonstrated the fact that the fiscal policy in Vietnam tends to be pro-cyclical. However, the study only focuses on measuring the fiscal impulse for the period prior to the global economic downturn, and does not provide a comprehensive analysis of the impact of the fiscal policy on the stabilizing of the economic cycle in Vietnam.

\section{The Limitations of the Earlier Research Studies and the Ways to Improve Presented in This Study}

The shortcomings of the existing studies in Vietnam are as follows:

- The theory of the fiscal policy in Vietnam and its role in stabilizing the economic cycle have been studied quite recently in the world, but in Vietnam no study really focuses on systemizing a framework of the various theories nor does any such study focus on providing a scientific basis containing guidance for a more-in-depth research study of reality. Therefore, most of the 
existing studies have been focused on carrying out qualitative analyses until now.

- International studies concentrate on building quantitatively analytical models, which is considered as the approach that could correctly assess the role of each fiscal instrument, so the policy recommendations are very coherent. The domestic studies of this issue of interest cannot keep pace with those international in terms of their lacking a quantitative analysis due to a variety of reasons, one of these being the absence of a theoretical framework that would be used as the scientific basis for building an econometric model, which has led to a limitation in researchers' research capacity.

- There is no study that would coherently and comprehensively generalize the lessons experienced regarding the implementation of the fiscal policy in the world. Most of the existing studies are focused on the real situation of the fiscal stance in Vietnam in different periods, suggesting some policy recommendations, but they are lacking in empirical evidence.

Therefore, the project is expected to fill all the emptiness in the literature on the fiscal policy in Vietnam, both in terms of theory and practice, towards stabilizing the economic cycle. Firstly, the project systemizes the framework of the theories, the analytical models applied in many other countries. Secondly, it provides scientific guidance for the domestic researcher to appropriately develop these theories and models under the conditions prevailing in Vietnam. Thirdly, the project directly provides the theoretical basis to the empirical study of the case of Vietnam. Fourthly, the project reviews the overall lessons experienced regarding the implementation of the fiscal policy in the world in a coherent and comprehensive manner, comparing the theories and different practice, which further empirical studies could be implemented and a relevant policy recommendation generated from.

\section{METHODOLOGY}

\section{The Research Model}

In the study, quantitative methods are used with a regression analysis based on the model of the economic growth theory by S. Devarajan et al (1996). The data used for the regression analysis have mainly been obtained from the Ministry of Finance, the World Bank, the Asian Development Bank and the GSO data. The specific model is as follows:

S. Devarajan et al (1996) developed the model of economic growth that covers the structure of the components of government spending and distinguishes between the cost-effective and ineffective components. Accordingly, the production function is assumed to represent the performance of a constant scale, with the inputs of the components of capital and government spending.

$$
Y=A K^{\alpha} G_{1}^{\beta} G_{2}^{1-\alpha-\beta}
$$

Where $Y$ is the output, $K$ is the capital stock, $G_{1}$ and $G_{2}$ are the two components of government spending, $A$ is the productivity level, and $\alpha, \beta$ are the intensity using the factor of production.

Assume that government spending is financed by a fixed tax rate $\tau$ on income, allowing the government to balance the budget in each period.

$$
G=G_{1}+G_{2}=\tau Y
$$

Call $\varphi$ is the share of the share of expenditure $G_{1}$ in the total government expenditure. Then

$$
\begin{aligned}
& G_{1}=\phi \tau Y \\
& G_{2}=(1-\phi) \tau Y
\end{aligned}
$$


The economy consists of the same households pursuing the goal of maximizing the benefits of their whole life cycle

$$
U=\int_{0}^{\infty} e^{-\rho t} U(C) d t
$$

With the benefit function of the form:

$$
U=\frac{C^{1-\sigma}-1}{1-\sigma} \quad \text { với } \quad \sigma \geq 0, \sigma \neq 1
$$

where $C$ is consumption, $1 / \sigma$ is interchangeable elasticity and $\rho$ is the discount rate. The capital accumulation made through investment comes from savings from after-tax income and consumption.

Call $\phi$ is the share of the share of the expenditure $G_{1}$ in the total government expenditure. Then

$$
\dot{K}=(1-\tau) Y-C-\delta K
$$

in which $\delta$ is the rate of the capital discount.

The optimal problem is established when the households maximize their life cycle benefits by choosing the level of drainage through the periods $C$, depending on the rate of capital accumulation.

$$
\begin{aligned}
& \operatorname{Max}_{C} \int_{0}^{\infty} e^{-\rho t} \frac{C^{1-\sigma}-1}{1-\sigma} d t \\
& \dot{K}=(1-\tau) Y-C-\delta K
\end{aligned}
$$

By combining Equations (1) and (2), the production function of the form is determined.

$$
Y=A^{1 / \alpha} \tau^{(1-\alpha) / \alpha}\left(\phi^{\beta}(1-\phi)^{1-\alpha-\beta}\right)^{1 / \alpha} K
$$

Then, the Halminton function:

$$
\begin{gathered}
H=\frac{C^{1-\sigma}-1}{1-\sigma}+\varphi\left(A^{1 / \alpha}(1-\tau) \tau^{(1-\alpha) / \alpha}\left(\phi^{\beta}(1-\phi)^{1-\alpha-\beta}\right)^{1 / \alpha} K-C-\delta K\right) \\
\frac{\partial H}{\partial C}=0 \Rightarrow C^{-\sigma}=\varphi
\end{gathered}
$$

$$
\dot{\varphi}=\rho \varphi-\frac{\partial H}{\partial K}=\rho \varphi-\varphi(1-\tau) \tau^{(1-\alpha) / \alpha}-\delta \varphi
$$

Take the time derivative of Equation (7)

$$
-\sigma \frac{\dot{C}}{C}=\frac{\dot{\varphi}}{\varphi}
$$

By combining Equations (8) and (9), we obtain the growth rate of consumption.

$$
\gamma=\frac{\dot{C}}{C}=\frac{1}{\sigma}\left(A^{1 / \alpha}(1-\tau) \tau^{(1-\alpha) / \alpha} \phi^{\beta / \alpha}(1-\phi)^{(1-\alpha-\beta) / \alpha}+\delta-\rho\right)
$$

In the equilibrium growth state, all the consumer variables $C$, the capital $K$ and the output $Y$ increase at the same rate. It can be seen in Equation (10) that the economic growth rate depends on the tax rate, or, also, that a share of the government expenditures depends on the total output and a share of the government expenditures depends on the total government expenditures $\Phi$.

When the size of government spending is concerned, it is clear that government spending has two opposite effects on economic growth. The positive impact originates from the goods and services the government provides (a higher government spending will provide more public services that increase the marginal productivity of capital and thus boost economic growth). The section showing the negative 
impact of taxation (an increase in the taxes that reduces after-tax income leads to reduced savings and a decrease in investment in capital and thus slows down economic growth).

The structure of government spending is determined by the composition of expenditure as a proportion of the total government expenditure. An assessment is made of the impact that government spending has on the effectiveness of each component of government spending. The composition of government spending is determined to be effective depending on the share of its impact on economic growth. Take the derivative of the economic growth rate under $\varphi$

$\frac{d \gamma}{d \phi}=\phi^{\beta / \alpha}(1-\phi)^{(1-\alpha-\beta) / \alpha}\left(\frac{\beta}{\alpha} \phi^{-1}-\frac{1-\alpha-\beta}{\alpha}(1-\phi)^{-1}\right)$

If $d \gamma / d \phi>0$ as the share of government spending increases, that will increase economic growth. Then, the component of government spending is called effective for economic growth. On the contrary, if $d \gamma / d \phi<0$, then the share of government spending increases, the economic growth rate decreases, and the component of government spending is consequently called ineffective for economic growth.

$$
\frac{d \gamma}{d \phi}>0 \Leftrightarrow \frac{\phi}{1-\phi}<\frac{1-\alpha-\beta}{\beta}
$$

It can be seen that the effectiveness of each component of government spending depends on (1) the relative weight between this and other government spending components, and (2) the relative proportion between them. The intensity factor uses the inputs of the components of government spending in the production function. The composition of government spending is determined to be effective when its relative share of the expenditure component is less than the ratio of the factor of intensity using the inputs between the two components of expenditure.

\section{Variables}

Regarding the independent variables, they are theoretically driven (Table 1).

Table 1 The variables

\begin{tabular}{|c|c|}
\hline Variables & Explanation \\
\hline \multicolumn{2}{|l|}{ Dependent variable } \\
\hline $\begin{array}{l}\text { The growth of the GDP per } \\
\text { capita }\end{array}$ & $\begin{array}{l}\text { The growth of the GDP per } \\
\text { capita }\end{array}$ \\
\hline \multicolumn{2}{|l|}{ Independent variables } \\
\hline $\begin{array}{l}\text { FD: The growth of } \\
\text { subsidies/GDP }\end{array}$ & $\begin{array}{l}\text { FD: The Growth of the } \\
\text { government subsidies per } \\
\text { GDP }\end{array}$ \\
\hline The growth of own revenue & $\begin{array}{l}\text { The growth of the own } \\
\text { revenue of the province }\end{array}$ \\
\hline Automatic stabilizers & $\begin{array}{l}\text { The automatic stabilizers of } \\
\text { the fiscal policy }\end{array}$ \\
\hline The direct tax rate & $\begin{array}{l}\text { The direct tax rate per total } \\
\text { revenue }\end{array}$ \\
\hline The indirect tax rate & $\begin{array}{l}\text { The indirect tax rate per } \\
\text { total revenue }\end{array}$ \\
\hline $\begin{array}{l}\text { The rate of export-import } \\
\text { revenue }\end{array}$ & $\begin{array}{l}\text { The rate of export-import } \\
\text { revenue per total revenue }\end{array}$ \\
\hline The log of non-tax revenue & The log of non-tax revenue \\
\hline $\begin{array}{l}\text { Domestic revenue/central } \\
\text { revenue }\end{array}$ & $\begin{array}{l}\text { Domestic revenue per } \\
\text { central revenue }\end{array}$ \\
\hline $\begin{array}{l}\text { The growth of investment } \\
\text { per GDP }\end{array}$ & $\begin{array}{l}\text { The growth of investment } \\
\text { per the GDP of the province }\end{array}$ \\
\hline Production expenditure & $\begin{array}{l}\text { The production expenditure } \\
\text { of the province }\end{array}$ \\
\hline Central expenditure & Central expenditure \\
\hline FDI per capita & FDI per capita \\
\hline The technology gap & $\begin{array}{l}\text { The technology gap } \\
\text { compared to Ho Chi Minh } \\
\text { city }\end{array}$ \\
\hline CPI & CPI \\
\hline The administrative level & $\begin{array}{l}\text { The administrative level: } \\
\text { Central Province: } 1 ; 0 \\
\text { otherwise }\end{array}$ \\
\hline The region & The region (6 regions) \\
\hline
\end{tabular}

Source: Author 


\section{Data}

The data used for the regression analysis have mainly been obtained from the Ministry of Finance (MoF), the World Bank, the Asian Development Bank and the GSO data. In addition, the observations with the missing values for the employed variables are excluded. Finally, the used dataset is an unbalanced panel data with 628 observations, with the descriptive statistics in Table 2.

\section{EMPIRICAL RESULTS AND DISCUSSION}

\section{Regressions}

In this section, the results of the simple and multiple regressions regarding the impact of the fiscal policy in Vietnam at the provincial level are analyzed. In general, the output is presented stepwise for firm fiscal decentralization (FD), the fiscal factors, and the context factors in order to facilitate comparisons with each other (Table 3).

Adding central government spending to localities does not appear to be economically viable. The results of the analysis indicate that central government subsidies for unplanned expenditures by local governments do not only appear to have had the negative effects on fiscal decentralization, but also on economic growth. Locally, while many localities often have to borrow from the state budget, there are some localities that lend this money, so that they cannot recover the amount of up to VND 3,200 billion (Labor Newspaper 2008).

Table 2 The descriptive statistics of the fiscal variables

\begin{tabular}{l|rrrrr|c}
\hline Variables & Obs. & \multicolumn{1}{c}{ Mean } & Std. Dev. & Min & \multicolumn{1}{c|}{ Max } & Source \\
\hline The growth of the GDP per capita & 630 & 1.915 .742 & 1.394 .837 & -3.449 .465 & 1.750 .587 & GSO \\
FD: The growth of the subsidies/GDP & 630 & 5.932 .826 & 4.484 .662 & -8.422 .443 & 6.490 .244 & MoF \\
The growth of own revenue & 628 & 3.367 .285 & 1.589 .821 & -8.162 .682 & 2.723 .698 & MoF \\
Automatic stabilizers & 691 & 5.149 .146 & 2.986 .202 & .9949532 & 1.774 .037 & MoF \\
The direct tax rate & 693 & 1.881 .201 & 2.080 .891 & 0 & 2.177 .335 & MoF \\
The indirect tax rate & 689 & 1.684 .971 & 1.735 .476 & .0540735 & 1.057 .244 & MoF \\
The rate of export-import revenue & 691 & 1.022 .463 & 1.546 .504 & 0 & 964.258 & MoF \\
The log of non-tax Revenue & 693 & 7.301 .263 & 1.383 .952 & 2.815 .409 & 1.173 .506 & MoF \\
Domestic revenue/central revenue & 693 & .0090291 & .0082562 & .0004358 & .0504733 & MoF \\
The growth of investment per GDP & 630 & .9231978 & 3.738 .582 & -7.755 .204 & 2.339 .768 & MoF \\
Production expenditure & 693 & 7.941 .014 & .7621969 & 614.975 & 1.039 .565 & MoF \\
Central expenditure & 693 & 1.336 .722 & .5147656 & 1.247 .876 & 1.405 .704 & MoF \\
FDI per capita & 693 & 2.698 .958 & 5.021 .977 & 0 & 4.942 .017 & GSO \\
The technology gap & 693 & -.0339105 & 4.405 .962 & -19 & 37 & GSO \\
CPI & 689 & 1.095 .896 & 6.331 .265 & 99.8 & 130.7 & GSO \\
The administrative level & 693 & .0793651 & .270503 & 0 & 1 & GSO \\
The region & 693 & 3.264 .069 & 1.825 .745 & 1 & 6 & GSO \\
\hline
\end{tabular}

Source: Author 
Table 3 The effects of the fiscal policy on growth in Vietnam in the period 2006-2015, the OLS model

\begin{tabular}{|c|c|c|c|c|c|}
\hline & $\begin{array}{l}\text { (1) } \\
\text { FD }\end{array}$ & $\begin{array}{c}\text { (2) } \\
\text { Automatic } \\
\text { stabilizers }\end{array}$ & $\begin{array}{c}\text { (3) } \\
\text { Revenues- } \\
\text { Taxes }\end{array}$ & $\begin{array}{l}\text { (4) } \\
\text { Expenditure } \\
\text { Structure }\end{array}$ & $\begin{array}{c}\text { (5) } \\
\text { Context }\end{array}$ \\
\hline FD: The growth of subsidies/GDP & $\begin{array}{c}-0.0899^{* * *} \\
(0.029)\end{array}$ & $\begin{array}{c}-0.0915 * * * \\
(0.029)\end{array}$ & $\begin{array}{c}-0.0866 * * * \\
(0.030)\end{array}$ & $\begin{array}{c}-0.0784^{* * *} \\
(0.027)\end{array}$ & $\begin{array}{c}-0.0590^{* *} \\
(0.024)\end{array}$ \\
\hline The growth of own revenue & $\begin{array}{l}0.0049 \\
(0.003)\end{array}$ & $\begin{array}{l}0.001^{*} \\
(0.003)\end{array}$ & $\begin{array}{l}0.0026 \\
(0.003)\end{array}$ & $\begin{array}{l}-0.0031 \\
(0.003)\end{array}$ & $\begin{array}{c}0.0016 \\
(0.003)\end{array}$ \\
\hline Automatic stabilizers & & $\begin{array}{l}0.0283 \\
(0.019)\end{array}$ & $\begin{array}{l}-0.0563 \\
(0.057)\end{array}$ & $\begin{array}{c}0.3124^{* * * *} \\
(0.065)\end{array}$ & $\begin{array}{c}0.1548 * * * \\
(0.058)\end{array}$ \\
\hline The direct tax rate & & & $\begin{array}{l}-0.4405 \\
(0.436)\end{array}$ & $\begin{array}{c}-0.7629^{*} \\
(0.414)\end{array}$ & $\begin{array}{l}-0.5832 \\
(0.463)\end{array}$ \\
\hline The indirect tax rate & & & $\begin{array}{l}-0.0125 \\
(0.086)\end{array}$ & $\begin{array}{l}-0.0596 \\
(0.085)\end{array}$ & $\begin{array}{l}-0.0497 \\
(0.067)\end{array}$ \\
\hline The rate of export-import revenue & & & $\begin{array}{l}0.1731^{*} \\
(0.099)\end{array}$ & $\begin{array}{c}-0.1677^{* *} \\
(0.085)\end{array}$ & $\begin{array}{l}-0.0480 \\
(0.065)\end{array}$ \\
\hline The log of non-Tax Revenue & & & $\begin{array}{l}-0.6459 \\
(0.666)\end{array}$ & $\begin{array}{l}0.1447 \\
(0.810)\end{array}$ & $\begin{array}{l}0.5477 \\
(0.744)\end{array}$ \\
\hline Domestic revenue/central revenue & & & $\begin{array}{c}395.5550 * * * \\
-143.396\end{array}$ & $\begin{array}{c}-1.33 \mathrm{e}+03^{* * *} \\
-217.090\end{array}$ & $\begin{array}{c}-716.0049 * * * \\
-203.205\end{array}$ \\
\hline The growth of investment per GDP & & & & $\begin{array}{c}-0.0648 * * * \\
(0.019)\end{array}$ & $\begin{array}{c}-0.0571^{* * * *} \\
(0.019)\end{array}$ \\
\hline Production expenditure & & & & $\begin{array}{l}11.813 \\
-1.133\end{array}$ & $\begin{array}{c}14.044 \\
-1.038\end{array}$ \\
\hline Central expenditure & & & & $\begin{array}{c}-20.7403^{* * *} \\
-2.402\end{array}$ & $\begin{array}{c}-11.0895^{* * *} \\
-2.660\end{array}$ \\
\hline FDI per capita & & & & & $\begin{array}{l}0.0060 \\
(0.021)\end{array}$ \\
\hline The technology gap & & & & & $\begin{array}{c}0.7265^{* * * *} \\
(0.125)\end{array}$ \\
\hline CPI & & & & & $\begin{array}{c}0.7291 * * * \\
(0.070)\end{array}$ \\
\hline The administrative level & & & & & $\begin{array}{l}-4.1069^{*} \\
-2.262\end{array}$ \\
\hline The region & & & & & $\begin{array}{c}-0.2060 \\
(0.317)\end{array}$ \\
\hline The constant & $\begin{array}{c}19.5378^{* * *} \\
(0.578) \\
\end{array}$ & $\begin{array}{c}18.0950^{* * * *} \\
(0.912)\end{array}$ & $\begin{array}{c}23.4128^{* * * *} \\
-4.097 \\
\end{array}$ & $\begin{array}{c}287.2106^{* * *} \\
-28.747 \\
\end{array}$ & $\begin{array}{c}74.7736^{* *} \\
-35.035 \\
\end{array}$ \\
\hline $\begin{array}{l}\text { The observations } \\
R^{2}\end{array}$ & $\begin{array}{c}628 \\
0.083 \\
\end{array}$ & $\begin{array}{c}628 \\
0.086 \\
\end{array}$ & $\begin{array}{c}628 \\
0.122 \\
\end{array}$ & $\begin{array}{c}628 \\
0.260 \\
\end{array}$ & $\begin{array}{c}628 \\
0.396 \\
\end{array}$ \\
\hline
\end{tabular}

The standard errors in parentheses

${ }^{*} p<.10, * * p<.05, * * * p<.01$

An asterisk $\left({ }^{*}\right),(* *),(* * *)$ denotes the statistical significance at least at the $10 \%, 5 \%$, and $1 \%$ levels, respectively. Model (1) presents the effects of Fiscal decentralization (FD) on the Growth of the GDP per capita of the province without the effect of the other factors. Model (2) presents the effects of FD on the growth and effect of Automatic stabilizers. Model (3) evaluates how the previous effects change under the effect of Revenues-Taxes. Model (4) investigates how these effects change under the effect of the Expenditure Structure. Model (5) presents the effects of the fiscal policy on growth under the context effect. 
The results of the other explanatory variables in the model are the same as it was expected by the author. The export, human capital accumulation, the growth of the labor market growth, the growth of the financial market, inflation, education and employment are also the important factors affecting the local economic development of the 63 provinces. The city of Vietnam. The reform of the financial and monetary market in Vietnam during the period 2002-2007 has had a positive impact on local economic growth. Therefore, the monetary and financial market reform should be continued in order to promote the economy in the long run and to effectively absorb foreign investment as well. So, in the future, using financial systems to monitor the revenues and expenditures of local governments will help accelerate economic growth and improve the quality of fiscal decentralization locally.

Although the decentralization of the management of the fiscal policy is practicable for developing countries such as Vietnam, the central government should pay close attention to the investment activities in the localities. In the early stages of economic development, the central government should undertake strategic investment projects so as to ensure the macroeconomic stability of the state, continue to refine the local civil servants that are ineffective and the quality workforce in order to ensure that a contingent of civil servants can effectively manage the fiscal policy and meet the expectations of the people. Large projects and projects of a national strategic nature must be attended and supervised by local residents. Finally, the central government continues to reform its financial and monetary markets in order to ensure the distribution and monitoring of local government spending and expenditures. Consequently, wasteful spending and corruption in expenditures on capital construction will be reduced.

In addition to this, the Fixed Effects-FE and Random Effects-RE methods that are considered to be effective and optimal are used in this paper to a greater extent than the traditional methods such as the OLS. The selection of the optimal methods is performed by doing the Hausman test and the Breusch and Pagan test.
After evaluating and satisfying the tests such as the Hausman test and the Breusch and Pagan test done in order to ensure an accurate estimation (Table 4), the Random Effects (RE) method is the optimum method of choice. The RE estimation method provides us with the following results.

\section{CONCLUSION}

The paper presents several contributions. The research provides an analysis of the effects of the fiscal policy on economic growth at the provincial level, bridging the gap in the recent research studies that are mostly focused on the national level. In addition, the findings will be supportive of the amending of annual and five-year provincial development planning in Vietnam. In addition, the investigation is emphasized by a comprehensive specification of fiscal decentralization, fiscal tools, the provincial-specific, regional and macroeconomic factors. Moreover, both the OLS model, with a robust option, and the Fixed Effects model are employed in order to help provide the unbiased estimates of the explanatory variables. As a further matter, the data cover the provinces in all the regions in the strongest period of economic globalization in Vietnam, from 2006 to 2015, which will help suggest an updated policy implication for Vietnam.

Generally speaking, the findings confirm the hypothesis that the fiscal policy in Vietnam supports provincial economic growth. The results encourage fiscal decentralization in terms of a reduction in the state subsidies intended for the province. There are the pieces of evidence that automatic stabilizers increase provincial economic growth in Vietnam. The findings have also confirmed that, in terms of indirect tax, the fiscal policy can successfully increase revenue, rather than it can be done by direct taxation. In addition to the said, the Vietnamese government should reduce the total budget expenditure at the central level so as to save the resource in order to sustainably develop its economic growth. 
Table 4 The effects of the fiscal policy on growth in Vietnam in the period 2006-2015, the random model

\begin{tabular}{|c|c|c|c|c|c|}
\hline & $\begin{array}{l}\text { (1) } \\
\text { FD }\end{array}$ & $\begin{array}{c}\quad(2) \\
\text { Automatic } \\
\text { stabilizers }\end{array}$ & $\begin{array}{c}(3) \\
\text { Revenues- } \\
\text { Taxes }\end{array}$ & $\begin{array}{c}\text { (4) } \\
\text { Expenditure } \\
\text { Structure }\end{array}$ & $\begin{array}{c}\text { (5) } \\
\text { Context }\end{array}$ \\
\hline FD: The growth of the subsidies/GDP & $\begin{array}{c}-0.0899 * * * \\
(0.012)\end{array}$ & $\begin{array}{c}-0.0915^{* * *} \\
(0.012)\end{array}$ & $\begin{array}{c}-0.0866^{* * * *} \\
(0.012)\end{array}$ & $\begin{array}{c}-0.0784^{* * *} \\
(0.011)\end{array}$ & $\begin{array}{c}-0.0590^{* * *} \\
(0.017)\end{array}$ \\
\hline The growth of own revenue & $\begin{array}{l}0.0049 \\
(0.003)\end{array}$ & $\begin{array}{l}0.0051 \\
(0.003)\end{array}$ & $\begin{array}{l}0.0026 \\
(0.003)\end{array}$ & $\begin{array}{l}-0.0031 \\
(0.003)\end{array}$ & $\begin{array}{l}0.0016 \\
(0.003)\end{array}$ \\
\hline Automatic stabilizers & & $\begin{array}{l}0.0283 \\
(0.018)\end{array}$ & $\begin{array}{l}-0.0563 \\
(0.055)\end{array}$ & $\begin{array}{c}0.3124^{* * *} \\
(0.065)\end{array}$ & $\begin{array}{c}0.1548^{* * *} \\
(0.048)\end{array}$ \\
\hline The direct tax rate & & & $\begin{array}{l}-0.4405 \\
(0.372)\end{array}$ & $\begin{array}{c}-0.7629 * * \\
(0.347)\end{array}$ & $\begin{array}{c}-0.5832^{*} \\
(0.338)\end{array}$ \\
\hline The indirect tax rate & & & $\begin{array}{l}-0.0125 \\
(0.102)\end{array}$ & $\begin{array}{l}-0.0596 \\
(0.098)\end{array}$ & $\begin{array}{l}-0.0497 \\
(0.053)\end{array}$ \\
\hline The rate of export-import revenue & & & $\begin{array}{l}0.1731 \\
(0.109)\end{array}$ & $\begin{array}{l}-0.1677 \\
(0.107)\end{array}$ & $\begin{array}{l}-0.0480 \\
(0.050)\end{array}$ \\
\hline The log of non-tax revenue & & & $\begin{array}{l}-0.6459 \\
(0.595)\end{array}$ & $\begin{array}{l}0.1447 \\
(0.727)\end{array}$ & $\begin{array}{l}0.5477 \\
(0.554)\end{array}$ \\
\hline Domestic revenue/central revenue & & & $\begin{array}{c}395.5550^{* *} \\
-155.197\end{array}$ & $\begin{array}{c}-1.33 \mathrm{e}+03^{* * *} \\
-229.582\end{array}$ & $\begin{array}{c}-716.0049^{* * *} \\
-183.974\end{array}$ \\
\hline The growth of investment per GDP & & & & $\begin{array}{c}-0.0648^{* * *} \\
(0.013)\end{array}$ & $\begin{array}{c}-0.0571^{* *} \\
(0.022)\end{array}$ \\
\hline Production expenditure & & & & $\begin{array}{r}11.813 \\
-1.309\end{array}$ & $\begin{array}{l}14.044 \\
(0.979)\end{array}$ \\
\hline Central expenditure & & & & $\begin{array}{c}-20.7403^{* * *} \\
-2.288\end{array}$ & $\begin{array}{c}-11.0895^{* * *} \\
-2.375\end{array}$ \\
\hline FDI per capita & & & & & $\begin{array}{l}0.0060 \\
(0.013)\end{array}$ \\
\hline The technology gap & & & & & $\begin{array}{c}0.7265^{* * *} \\
(0.110)\end{array}$ \\
\hline CPI & & & & & $\begin{array}{c}0.7291 * * * \\
(0.059)\end{array}$ \\
\hline The administrative level & & & & & $\begin{array}{c}-4.1069^{*} \\
-2.314\end{array}$ \\
\hline The region & & & & & $\begin{array}{r}-0.2060 \\
(0.251)\end{array}$ \\
\hline The constant & $\begin{array}{c}19.5378^{* * *} \\
(0.550)\end{array}$ & $\begin{array}{c}18.0950 * * * \\
-1.091 \\
\end{array}$ & $\begin{array}{c}23.4128 * * * \\
-3.863 \\
\end{array}$ & $\begin{array}{c}287.2106 * * * \\
-28.001 \\
\end{array}$ & $\begin{array}{c}74.7736 * * \\
-30.310 \\
\end{array}$ \\
\hline $\begin{array}{l}\text { The observations } \\
R^{2}\end{array}$ & 628 & 628 & 628 & 628 & 628 \\
\hline
\end{tabular}

The standard errors in parentheses

${ }^{*} p<.10, * * p<.05, * * * p<.01$

An asterisk $(*),(* *),(* * *)$ denotes the statistical significance at least at the $10 \%, 5 \%$, and $1 \%$ levels, respectively. Model (1) presents the effects of Fiscal decentralization (FD) on the growth of the GDP per capita of the province without the effect of the other factors. Model (2) presents the effects of FD on growth and effect of Automatic stabilizers. Model (3) evaluates how the previous effects change under the effect of Revenues-Taxes. Model (4) investigates how these effects change under the effect of the Expenditure Structure. Model (5) presents the effects of the fiscal policy on growth under the context effect. 
The government should launch a comprehensive master plan for a medium and long-term fiscal and monetary policy, in which the balance-of-payments and public investment balances should be calculated in conjunction with the research. The total means of payment and credit growth. In the time of the need for restructuring investment today, the Government needs to have specific studies for each sector of public investment that can reasonably allocate state capital. In addition, the government needs to closely monitor public investment so as to ensure the effectiveness of these funds.

Besides, the paper has some limitations that a further research study may eliminate. The other control variables, such as monetary supply, the credit flow, and the total capital. A further research study could investigate a longer period of time in order to facilitate the comparison between the periods of time with different fiscal policies.

\section{ACKNOWLEDGMENT}

This article is based on the results of a study funded by the National Foundation for Science and Technology Development (NAFOSTED), under the research project "Fiscal Policy Theoretical Framework for Cyclical Stability" International Code II1.992013.43

\section{REFERENCES}

Aiyagari, S. R., Christiano, L. J., \& Eichenbaum, M. (1992). The output, employment, and interest rate effects of government consumption. Journal of Monetary Economics, 30(1), 73-86. doi.org:10.1016/0304-3932(92)90045-4

Akai, N., \& Sakata, M. (2002). Fiscal decentralization contributes to economic growth: Evidence from state-level cross-section data for the United States. Journal of Urban Economics, 52(1), 93-108. doi.org:10.1016/S0094-1190(02)00018-9

Baxter, M., \& King, R. G. (1993). Fiscal policy in general equilibrium. The American Economic Review, 83(3), 315-334.

Bernanke, B. S. (1986). Alternative explanations of the moneyincome correlation. Carnegie-Rochester Conference Series on Public Policy, 25(1), 49-99. doi.org/10.1016/0167-2231(86)90037-0
Blanchard, O., \&Perotti, R. (2002). Anempiricalcharacterization of the dynamic effects of changes in government spending and taxes on output. Quarterly Journal of Economics, 117(4), 1329-1368. doi.org/10.1162/003355302320935043

Davoodi, H., \& Zou, H. (1998). Fiscal decentralization and economic growth: A cross-country study. Journal of Urban Economics, 43(2), 244-257. doi.org/10.1006/juec.1997.2042

Debrun, X., \& Kapoor, R. (2010). Fiscal policy and macroeconomic stability: Automatic stabilizers work always and everywhere. IMF Working Paper WP/10/111.

Devarajan, S., Swaroop, V., \& Zou, H. F. (1996). The composition of public expenditure and economic growth. Journal of Monetary Economics, 37(2), 313-344. doi.org/10.1016/ S0304-3932(96)90039-2

Dinh, H. M. (2005). Constructing indexes for short-term economic analysis and forecasting - International experience and capacity building for Vietnam. MPI project, Vietnam.

Floden, M. (2012). A role model for the conduct of fiscal policy? Experiences from Sweden. Journal of International Money and Finance, 34, 177-197. doi.org/10.1016/j.jimonfin.2012.11.010

Furceri, D., \& Mourougane, A. (2010). The effects of fiscal policy on output: A DSGE analysis. Working paper, OECD Economics Department. doi.org/10.1787/5kmfp4z3njg0-en

Garry, J. S. (1986). International comparisons of fiscal policy: The OECD and the IMF measures of fiscal impulse. International Finance Discussion Papers 274, Board of Governors of the Federal Reserve System (US).

Gutiérrez, M., \& Revilla, J. E. (2011). Building countercyclical fiscal policies in Latin America - The international experience. World Bank Policy Research Working Paper No. 5211.

Kriwoluzky, A. (2009). Pre-announcement and timing: The effects of a government spending shock. European Economic Review, 56(3), 373-388. doi.org/10.1016/j. euroecorev.2011.10.005

Labor Newspaper. (2008).

Le, Q. T. (2017). Measuring fiscal impulse for Vietnam. Economics \& Development Journal, 235, 32-40.

Leeper, E. M., Walker, T. B., \& Yang, S. S. (2008). Fiscal foresight: Analytics and econometrics. NBER Working Paper. doi:10.2139/ssrn.1132442 
Lorenzo, F., Libero, M., \& Luca, S. (2009). The general equilibrium effects of fiscal policy: Estimates for the Euro area. Journal of Public Economics, 93(3-4), 559-585. doi:10.1016/j.jpubeco.2008.09.010

Mertens, K., \& Ravn, M. O. (2012). Empirical evidence on the aggregate effects of anticipated and unanticipated U.S. tax policy shocks. American Economic Journal: Economic Policy, 4(2), 145-181. doi:10.1257/pol.4.2.145

Mountford, A., \& Uhlig, H. (2008). What are the Efects of Fiscal Policy Shocks? NBER Working Paper, no. 14551. doi:10.3386/ w14551

Nguyen, N. A., Nguye, D. C., Nguyen, D. N., \& Bui, T. H. (2010). Fiscal issue in Vietnam economy: Assessment on the impact of stimulus, fiscal transparency and fiscal risk. CHAPTER 8. Assessment on the impact of stimulus, fiscal transparency and fiscal risk. ERIA Research Project Report 2010, No. 1.

Nguyen, P. L., \& Anwar, S. (2011). Fiscal decentralisation and economic growth in Vietnam. Journal of the Asia Pacific Economy, 16(1), 3-14. doi:10.1080/13547860.2011.539397

Nguyen, T. K. T. (2013). Fiscal policy and fiscal policy: Issues to coordinate. Journal of Economics and Development, 267, $23-28$.

Nguyen, T. N. (2014): Tăng cường hiệu quả chi tiêu ngân sách ở Việt Nam. Tạp chí quản lý kinh tế, 61, 21-30. (Enhancing the efficiency of budget expenditure in Vietnam). Vietnam economic management review, 61, 21-30.

Perotti, R. (2005). Estimating the effects of fiscal policy in OECD countries. CEPR Discussion Paper.
Ramey, V. A. (2008). Identifying government spending shocks: It's all in the timing. NBER Working Paper No. 15464. doi: 10.3386/w15464

Ramey, V. A., \& Shapiro, M. D. (1998). Costly capital reallocation and the effects of government spending. Carnegie-Rochester Series on Public Policy, 48(1), 145-194. doi.org/10.1016/S01672231(98)00020-7

Renee, P., \& John, J. (2002). Indicators of fiscal impulse for $\mathrm{New}$ Zealand. New Zealand Treasury Working Paper 02/30.

Shaheen, R., \& Turner, P. (2010). Measuring the dynamic Effects of Fiscal Policy shocks in Pakistan. 25 $5^{\text {th }}$ Agm Pide Pakistan, $28^{\text {th }}-30^{\text {th }}$ December 2010, Islamabad, Pakistan.

Stansel, D. (2005). Local decentralization and local economic growth: A cross-sectional examination of US metropolitan areas. Journal of Urban Economics, 57(1), 55-72. doi. org/10.1016/j.jue.2004.08.002

$\mathrm{Su}, \mathrm{D}$. T. (2013). The effect of public expenditure thresholds and economic growth in Vietnam is tested by Boostrap method. Journal of Economics and Development, 26(8), 12-22.

$\mathrm{Vu}$, D. A. (2011). Fiscal policy and coordination with monetary policy - Some lessons from 2006-2010. Vietnam economic conference issues in the medium and long term.

Xie, D., Zou, H., \& Davoodi, H. (1999). Fiscal decentralization and economic growth in the United States. Journal of Urban Economics, 45(2), 228-239. doi.org/10.1006/juec.1998.2095

$$
\begin{array}{r}
\text { Received on } 17^{\text {th }} \text { July } 2017, \\
\text { after revision, }
\end{array}
$$

Nguyen Thi Nguyet is a researcher $(\mathrm{PhD})$ at the Central Institute for Economic Management Ministry of Planning and Investment, Hanoi City, Vietnam. Also, he is a member of the Editorial Board of the Vietnam Economic Management Review, whose publisher is the Central Institute for Economic Management - Ministry of Planning and Investment, Hanoi City, Vietnam. 


\title{
FISKALNA POLITIKA I POKRAJINSKI RAST: SLUČAJ VIJETNAMA
}

\author{
Nguyen Thi Nguyet \\ Central Institute for Economic Management (CIEM) - Ministry of Planning and Investment (MPI), \\ Hanoi City, Vietnam
}

Istraživanje u ovom radu fokusirano je na procenu uticaja fiskalne politike na ekonomski rast u Vijetnamu, na pokrajinskom nivou. Fiskalna politika ima ogromnu ulogu u nacionalnoj ekonomiji. Kreatori politika često primenjuju fleksibilnu fiskalnu i monetarnu politiku, u cilju ostvarivanja sveukupnog ekonomskog rasta. Da bi se izvršila procena uticaja instrumenata fiskalne politike na ekonomski rast, u radu je primenjena integrisana analiza $u$ kombinaciji sa kvantitativnim analizama, radi pronalaženja veze između ključnih rashodovnih stavki. Vlada utiče na ekonomski rast. Rezultati istraživanja upućuju na potrebu kritičkog preispitivanja odnosne politike.

Ključne reči: fiskalna politika, fiskalna decentralizacija, porez, rashod, rast

JEL Classification: $\mathrm{H} 30, \mathrm{H} 70, \mathrm{H} 2 \mathrm{O}$ 